\title{
Salinity requirements for successful spawning of Baltic and Belt Sea cod and the potential for cod stock interactions in the Baltic Sea
}

\author{
Anders Nissling ${ }^{1,2, *}$, Lars Westin $^{1}$ \\ ${ }^{1}$ Department of Systems Ecology, Stockholm University, S-106 91 Stockholm, Sweden \\ ${ }^{2}$ Institute of Marine Research, PO Box 4, S-453 21 Lysekil, Sweden
}

\begin{abstract}
The brackish water of the Baltic Sea, with decreasing salinity from the west to the east and from the south to the north, is a borderline area for cod Gadus morhua. The major stock, the eastern Baltic cod, has decreased substantially during the last decade. A discussion concerning the possibility of immigration of cod and the potential of stock interactions has evolved. The present study was conducted in order to elucidate if differences in salinity requirements for successful spawning exist between the eastern Baltic cod and the western Belt Sea cod, and if adaptation to ambient salinity is possible. Activation of the spermatozoa occurred at $\geq 11$ to 12 psu (practical salinity units) for Baltic cod and at $\geq 15$ to 16 psu for Belt Sea cod. Neutral egg buoyancy was obtained at $14.5 \pm 1.2$ psu and at 20 to 22 psu respectively. Transfer of fish from marine to brackish water conditions showed that these characteristics remained essentially the same; activation of spermatozoa occurred at $\geq 14$ to 15 psu and neutral egg buoyancy at 19 to 21 psu. The results suggest that these characteristics are specific to populations. Regarding hydrographic conditions in the spawning areas of cod in the Baltic, the results suggest that stock interactions may be possible in the western Baltic spawning areas where salinity requirements for both stocks are fulfilled, but not in the eastern spawning areas as low salinity prevents successful spawning of Belt Sea cod. Salinity and oxygen conditions in the Baltic vary with highly irregular saline water inflows. Periods of stagnation without inflows may, due to decreasing salinity, e.g. $<15$ psu during the last stagnation period, act as an ecological barrier separating the stocks.
\end{abstract}

KEY WORDS: Gadus morhua $\cdot$ Stock discrimination $\cdot$ Salinity $\cdot$ Spawning $\cdot$ Spermatozoa $\cdot$ Fertilization Egg buoyancy - Baltic Sea

\section{INTRODUCTION}

Atlantic cod Gadus morhua is distributed in relation to shelf topography, current systems and temperature regime in coastal and continental shelf areas in the northern Atlantic Sea (Brander 1994) and is generally regarded as a number of populations or stocks according to distribution and habits. Stocks have been differentiated by meristic and morphometric characteristics, analysis of genetic variation in haemoglobin type, various tissue enzymes, and mitochondrial and nuclear DNA. Evidence for stock discrimination exists for dif-

\footnotetext{
-Address for correspondence: Institute of Marine Research,
} PO Box 4, S-453 21 Lysekil, Sweden. E-mail: a.nisslıng(®imr.se ferent regions, e.g. in Norwegian waters the ArctoNorwegian cod differs from the Norwegian coastal cod (Dahle 1991, Dahle \& Jørstad 1993, Fyhn et al. 1994) both spawning in the same area off Lofoten, Norway. However, Mork et al. (1985) concluded, using alloenzyme frequency analysis, that there is little genetic variation throughout most of its range, although a relatively large genetic distance was recorded between Baltic and Atlantic cod stocks. In the brackish water of the Baitic Sea, cod is at the border of its distribution and is generally divided into 2 stocks, the eastern Baltic cod stock, present east of the island Bornholm, Denmark [ICES subdivisions (SDs) 25 to 32], and the western Belt Sea cod stock, present in the Arkona Basin and the Belt Seas (ICES SDs 22 to 24). The longi- 


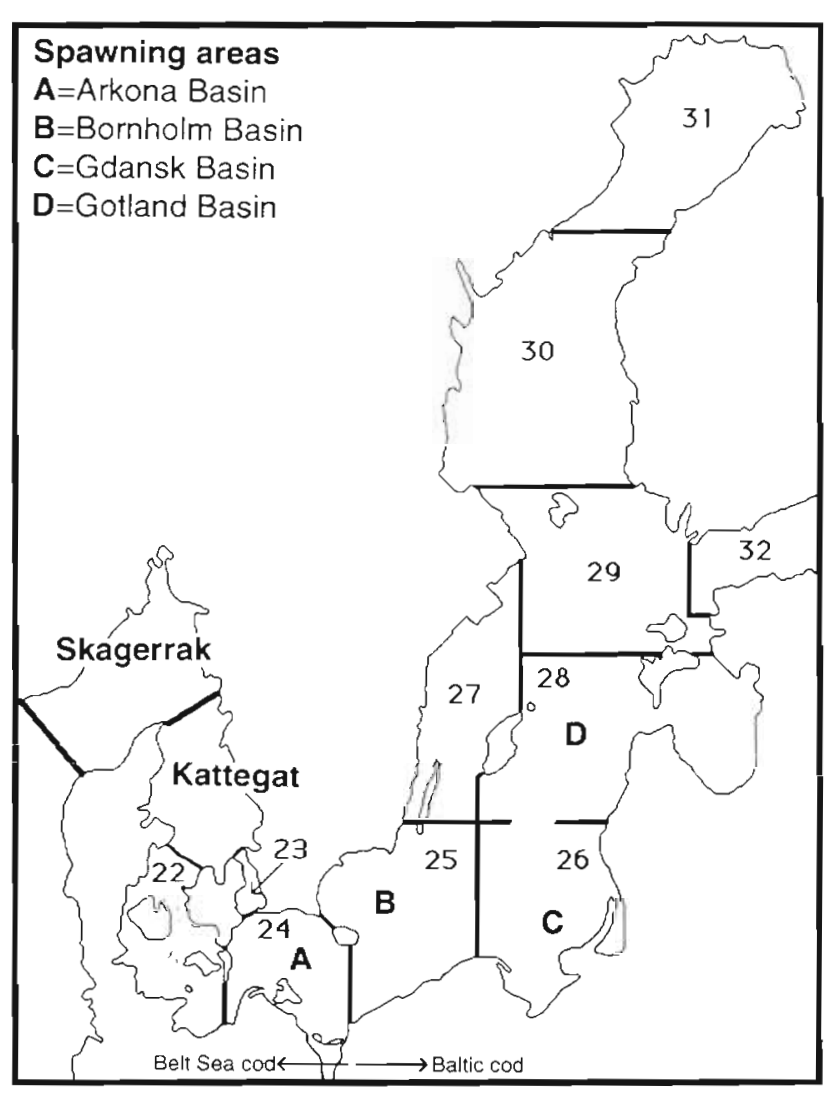

Fig. 1. ICES statistical subdivisions (SDs) in the Baltic Sea, the longitude $14^{\circ} 30^{\prime} \mathrm{E}$ (Lne between SD 24 and SD 25), and spawning areas (shaded areas) of BaItic and Belt Sea cod Gadus morhua (after Bagge \& Thurow 1993)

tude $14^{\circ} 30^{\prime} \mathrm{E}$ is generally regarded as the border line (Bagge \& Steffensen 1989, Bagge et al. 1994) (Fig. 1). The discrimination is based on meristic and morphometric characteristics as well as on haemoglobin types and various alloenzymes (see Bagge \& Steffensen 1989, Bagge et al. 1994).

Saline water flows from the North Sea into the Baltic through The Sound and the Danish Belts under certain meteorological conditions (Fonselius 1962, 1988, Franck et al. 1987. Matthäus 1993). Consequently, salinity in the Baltic decreases from the west to the east and from the south to the north, ranging between 8 and 3 psu in the surface layer and between 18 and 10 psu in the deep basins below the halocline. Salinity is a major factor influencing the spawning success of Baltic cod (Grauman 1973, 1974, Westin \& Nissling 1991, Nissling et al. 1994). The eastern Baltic cod is adapted to spawning at the salinities that prevail in the eastern Baltic deep basins. Activation of the spermatozoa, and thus fertilization, occurs at $\geq 11$ to 12 psu (Westin \& Nissling 1991) and neutral egg buoyancy is achieved at 12 to 18 psu (Nissling et al. 1994). The western Baltic cod spawn in areas with salinities ranging from about
15 psu to fully marine conditions in the transition area between the Baltic and the Kattegat (The Sound and the Danish Belts) (spawning areas shown in Fig. 1).

According to tagging experiments cod from the western stock may undertake migration eastwards, sometimes as far as to the southern Gotland Basin (SD 28), whereas westward migration by individuals from the eastern stock is limited (Aro 1989, Bagge \& Steffensen 1989). Individuals from the western stock may in addition be transported eastwards during periods of inflows of saline water into the Baltic as eggs, larvae or pelagic juveniles (see Westerberg 1994). Such transport might in some years be substantial as indicated by bimodal length distribution of 1 -group cod in the area around the island Bornholm (SDs 24 and 25) in some years (A.-C. Larsson \& P.-O. Rudolphi, Institute of Marine Research, Lysekil, Sweden, unpubl.).

Adaptation to environmental conditions occurs as phenotypic plasticity and through genetic selection. In phenotypic plasticity individuals within a population adapt to environmental variability by changes in behaviour and physiology without genotypic changes as they may be altered within a generation. Genetic selection, on the other hand, occurs as a result of some individuals being more successful than others in adapting to changed environmental conditions, resulting in a higher proportion of their offspring in the population. This evolutionary process may imply changes in genotypic frequencies as it occurs over generations. Genetic differences between groups of individuals in a population will evolve if the genetic flow is restricted. The flow of genes necessary for preventing differentiation depends on the strength of the forces causing the differentiation (Chakraborty \& Leimar 1987).

Cod and a number of other marine fish species have colonized the Baltic Sea following the last glacial period. The selection pressure for adapting to the brackish environment in the Baltic has probably been strong with salinity acting as an evolutionary force. Individuals or species not able to adapt to brackish conditions for spawning did not colonize the Baltic while those with higher phenotypic plasticity, able to successfully cope with low salinity at spawning, produced offspring entering a virgin area.

In previous investigations (Westin \& Nissling 1991, Nissling et al. 1994) we studied neutral egg buoyancy and spermatozoa mobility of the eastern Baltic cod at different salinities with implications for opportunities for fertilization and egg development, i.e. spawning success, in relation to saline water inflows into the Baltic. The aim of the present study was to study differences in salinity requirements for successful spawning between Belt Sea and Baltic cod, using the same methodology as in previous investigations, and to study the potential for adaptation of these characteris- 
tics to ambient salinity. A reciprocal transplant study was used to elucidate phenotypic plasticity. Cod of marine origin were transferred to brackish conditions and Baltic cod (brackish origin) were transferred to marine conditions prior to spawning.

The investigation was conducted in light of the scenario put forward by Elmgren et al. (1989): the dramatic decline in the stock size of eastern Baltic cod from the mid 1980s (Hansson \& Rudstam 1990, Bagge et al. 1994) might release a feeding niche and thus perhaps westward immigration to the eastern parts and, possibly, interaction with the eastern stock. This would potentially cause a 'genetic degeneration' of the eastern Baltic cod adapted to the brackish water condition by selection. Our primary interest was to evaluate if individuals from the western stock are able to spawn successfully in the less saline water of the eastern Baltic deep basins, the Bornholm, Gdansk and Gotland basins, and thereby interbreed with the eastern cod.

\section{MATERIAL AND METHODS}

The investigation includes cod from ICES SDs 23, 24, 25 and 28 in the Baltic as well as cod from the Gullmaren fjord, Sweden $\left(58^{\circ} \mathrm{N}, 11^{\circ} \mathrm{E}\right)$ in the Skagerrak. In the Baltic, fish were caught with gill nets or by trawling and in the Gullmaren fjord, fyke nets were used. Measurements were carried out during 1991 to 1995 either directly, on spawning fish caught during surveys with RV 'Argos', or on fish caught prior to spawning and kept in tanks until start of spawning. Fish were transported either to the Ar laboratory, Gotland, Sweden, in the middle of the Baltic, where the fish were kept in indoor tanks provided with running water of about 7 psu, or to the Institute of Marine Research, Lysekil, Sweden, where fish were maintained at 30 to 34 psu.

Measurements were performed on fish in their natural environment, i.e. on spawning fish caught during cruises with RV 'Argos', on fish caught in brackish conditions off Gotland (SD 28) and kept at 7 psu and on fish of marine origin caught in the Gullmaren fjord (salinity of surface layer 18 to 30 psu and $>34$ psu in deep water below the halocline) and maintained at 30 to 34 psu. Measurements were also performed on fish transferred from marine to brackish water conditions and vice versa designed as a reciprocal transplant experiment. Cod from the Gullmaren fjord and from The Sound (SD 23), i.e. inhabiting areas with salinity ranging from 18 to $>34$ psu, were transferred to the Ar laboratory, Gotland (brackish conditions), 3 to 4 mo before spawning, and cod of brackish origin, caught in the eastern Baltic (SDs 25 and 28), were transferred to marine conditions at the Institute of Marine Research, Lysekil, 3 to 6 mo before spawning.
Spermatozoa activity. Spermatozoa activity at different salinities was studied during 5 min of observation at approximately $7^{\circ} \mathrm{C}$ under a microscope at $250 \times$ magnification using a nominal scale: swimming, vibrating or immobile. For each determination, semen was sampled directly from the male using a dry Pasteur pipette as described in Westin \& Nissling (1991). For each salinity tested, 1 droplet of semen was diluted in approximately $5 \mathrm{ml}$ of water, prepared from synthetic seasalt (hw Marinemix, Wiegandt, Germany) and deionized water, and observation was made immediately. For each male, measurements were carried out, starting with a high salinity followed by subsequently lower salinities until spermatozoa mobility ceased, i.e. the salinity at which fertilization is not possible (see Westin \& Nissling 1991); this was followed by a measurement at a higher salinity to ensure that the semen still was of good quality.

Fertilization. Fertilization success at different salinities was studied by mixing eggs and semen artificially at $\sim 7^{\circ} \mathrm{C}$, using eggs obtained by stripping and semen collected with a dry Pasteur pipette. Water of different salinities was prepared either by addition of synthetic seasalt (hw Marinemix) to or by dilution with deionized water of filtered $(0.2 \mu \mathrm{m}$ ) seawater ( 7 or 30 to $34 \mathrm{psu}$ ). In each set of experiments, eggs from 1 female and semen from 1 male were mixed at 6 or 7 salinities (at $10,11,12,13,20$ and 30 psu for Baltic cod; at 14, 15, 16, $17,18,20$ and 30 psu for Gullmaren cod; and at 11, 12, $13,14,15$ and 16 psu for Baltic cod raised in marine conditions). One droplet of fresh semen was mixed with $\sim 100 \mathrm{ml}$ water of each salinity and a spoonful ( 1000 eggs) of eggs was added immediately. About $2 \mathrm{~h}$ after fertilization the eggs were rinsed in water (respective salinity) and incubated further in $300 \mathrm{ml}$ water (respective salinity) at $7^{\circ} \mathrm{C}$. A subsample of eggs ( $\geq 200$ eggs) was collected 6 to $8 \mathrm{~h}$ after fertilization and the number of fertilized eggs counted. Eggs with 4 cells or more were considered fertilized as opposed to activated eggs, i.e. eggs with 1 germinal cell but without cell cleavages (see Howell et al. 1991), and eggs without cells.

Egg buoyancy and egg size. Eggs for buoyancy measurements were obtained by stripping. Determinations were performed on unfertilized eggs or on eggs in the blastula stage ( $1 \mathrm{~d}$ old) after fertilization at $17 \mathrm{psu}$ (cod from the Baltic) or at 30 psu (cod from the Gullmaren fjord) at $7^{\circ} \mathrm{C}$. As evident from earlier investigations (Nissling \& Westin 1991) no differences in egg specific gravity occur between unfertilized and 1 d old eggs, and differences in egg specific gravity due to different salinities at fertilization are of minor importance [differences in salinity of neutral buoyancy $<0.5$ psu when eggs from the same batch were fertilized at both 17 and at 30 psu (L. Vallin, Department of Systems 
Ecology, Stockholm University, Sweden, pers, comm., authors' obs.)]. Determinations of egg specific gravity were carried out at $7^{\circ} \mathrm{C}$ using a density gradient column, according to Coombs (1981). The positions of the eggs were compared with the positions of 6 density floats of known specific gravity. For each egg batch 10 to 15 eggs were used. The linearity between specific gravity of the density floats and their positions was high $(r>0.99)$ at all determinations.

Egg size was measured under a stereomicroscope at $50 \times$ magnification using a micrometer scale. For each egg batch, 15 eggs in the blastula stage were used.

Osmolality measurements. Osmolality in seminal. plasma and ovarian fluid was measured by freezing point depression using an osmometer. Ovarian fluid was obtained by letting fluid from a batch of eggs run off from a net and semen by sampling directly from the male using a Pasteur pipette. The samples were kept cool until centrifuged and analysed. Each sample was analysed in replicate and results calculated into psu by comparing determinations with a standard of $300 \mathrm{mOsmol} \mathrm{l^{-1 }}$ (salinity 9.8 psu) prepared from $\mathrm{NaCl}$.

\section{RESULTS}

\section{Spermatozoa activity and fertilization}

Duration of spermatozoa mobility at different salinities for Baltic and for Gullmaren cod is shown in Fig. 2. For Baltic cod kept in ambient brackish conditions (Fig. 2a) the spermatozoa were activated at 11 to 12 psu. At 11 psu most males displayed vibrating
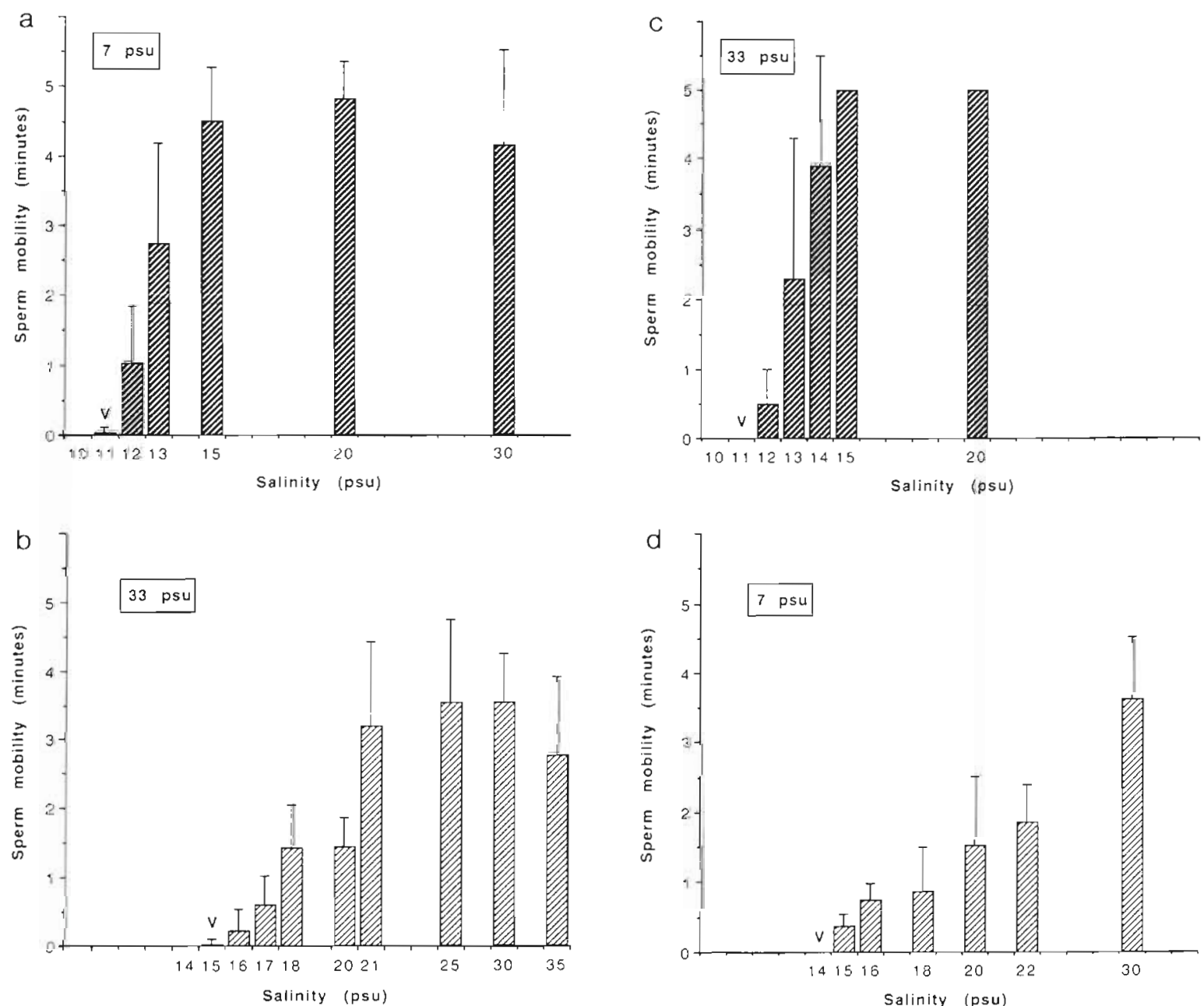

Fig. 2. Gadus morhua. Duration of sperm mobility of Baltic and Gullmaren cod at different salinıties during 5 min of observation ( $V$ indicates vibrating, non swimming spermatozoa). (a) Baltic cod kept at 7 psu $(n=8)$, (b) Gullmaren cod kept at 30 to 34 psu $(\mathrm{n}=11)$. (c) Baltic cod kept at 30 to 34 psu ( $n=8)$, and (d) Gullmaren cod kept at 7 psu ( $n=10)$. Standard deviation given on top of bars 
spermatozoa. Swimming spermatozoa occurred for all males from 12 psu with increased mobility with increasing salinity up to $15 \mathrm{psu}$ and high mobility at higher salinities. The spermatozoa of marine cod from the Gullmaren fjord, kept in marine conditions, were activated at 15 to 16 psu (Fig. 2b). Most males displayed vibrating spermatozoa at 15 psu with mobility increasing with salinity up to 21 psu and high mobility at higher salinities.

The percentage of fertilized eggs at different salinities is shown in Fig. 3. For Baltic cod in brackish conditions (Fig. 3a) successful fertilization occurred at salinities of 11 to 12 psu and higher, whereas fertilization occurred at $\geq 15$ to 16 psu for Gullmaren cod kept in marine conditions (Fig. 3b). Fertilization ranged from 0 to $98 \%$ for Baltic cod at 11 psu and between 0 and $7 \%$ for Gullmaren cod at 15 psu, corresponding to the salinity of onset of spermatozoa activity for the 2 stocks.

In Fig. 2c, d, sperm mobility at different salinities is shown for cod transferred from a brackish to a marine environment (Fig 2c) and from marine to brackish water conditions (Fig. 2d) respectively. Compared to when kept in their natural enviromment, salinity of spermatozoa activation and spermatozoa mobility remained essentially the same. The spermatozoa of Baltic cod remained active down to 12 psu and the spermatozoa of Gullmaren cod to 15 psu. However, spermatozoa mobility was somewhat affected at low salinities. When Baltic cod were transferred to marine conditions, immobile or merely vibrating spermatozoa were recorded at 11 psu and only some males displayed swimming spermatozoa at 12 psu. When cod from the Gullmaren fjord were transferred to brackish water conditions, spermatozoa activity increased somewhat at low salinities. Vibrating spermatozoa were noted at 14 psu and all males displayed swimming spermatozoa at 15 psu. This effect of ambient salinity was confirmed in a fertilization experiment in which 2 Baltic cod females, kept at 30 to 34 psu, were fertilized with spermatozoa from Baltic cod males kept at 7 and 30 to 34 psu respectively (Fig. 4). Fertilization was, at least at low salinities, higher for males kept in brackish water conditions than when males maintained in marine conditions were used, i.e. fertilization success at low salinities was somewhat affected by ambient salinity of the male.

From the above it is evident that fertilization success is highly influenced by spermatozoa mobility and that fertilization success is affected by ambient salinity. Dif-
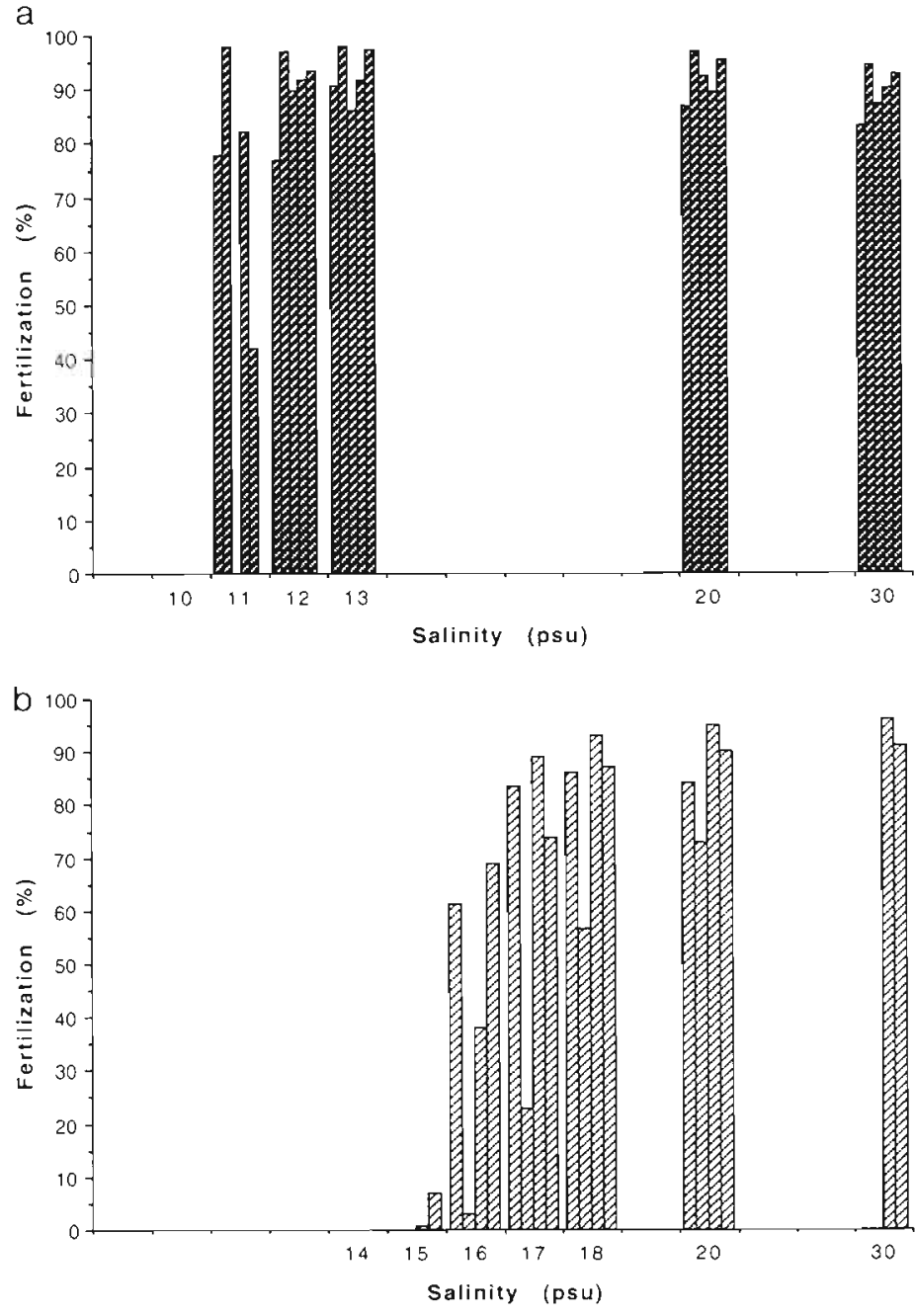

Fig. 3. Gadus morhua. Percentage of fertilized eggs of Baltic and Gullmaren cod after fertilization at different salınities. (a) Baltic cod kept at 7 psu ( $n=5$ ), (b) Gullmaren cod kept at 30 to 34 psu ( $n=4$ )

ferences in spermatozoa mobility at different salinities exist between Baltic cod and cod of marine origin (Gullmaren cod), and transfer of fish showed that salinity of spermatozoa activation remained the same, only to a small extent affected by ambient salinity (Fig 2). In Fig. 5 the percentage of fertilized eggs at different salinities is shown for the fertilization experiment in which 3 Baltic cod males, raised and maintained in marine conditions ( 30 to 34 psu), were used. Although raised in marine conditions they were potent to fertilize eggs at 12 psu, i.e. activation of the spermatozoa occurred at the same salinity as when caught in brackish conditions and transferred to marine conditions (Fig. 2c). This shows that salinity of spermatozoa activation is a stable characteristic, specific for respective stock, and not affected by ambient salinity during development. 

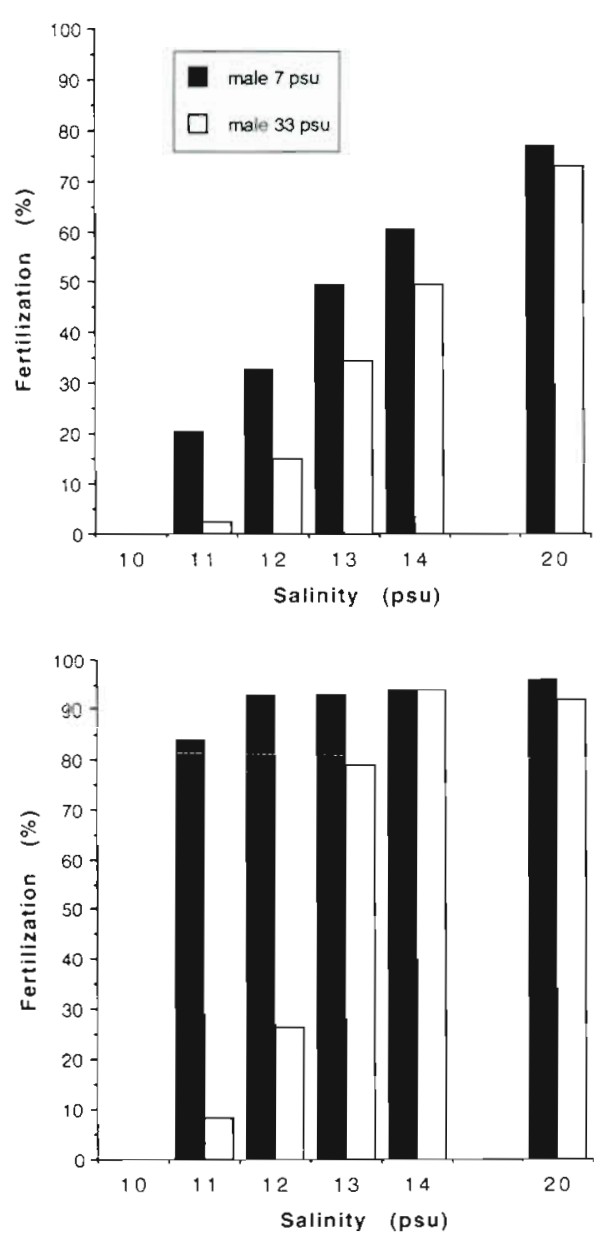

Fig. 4. Gadus morhua. Percentage of fertilized eggs of Baltic cod after fertilization at different salinities with males kept at brackish and marine conditions respectively (2 identical setups with different males and females)

\section{Egg specific gravity and egg size}

Salinity of neutral buoyancy of 53 egg batches of Baltic cod and 13 batches of cod from the Gullmaren fjord, kept at 7 and 30 to 34 psu respectively, is shown in Fig. 6. Salinity of neutral egg buoyancy was obtained at $14.5 \pm$ 1.2 psu and at $21.4 \pm 1.3$ psu respectively, i.e. egg specific gravity of the stocks differed (Table 1). Transfer of cod of marine origin from the Gullmaren fjord to brackish conditions revealed only a minor change in salinity of neutral buoyancy (Table 1). Salinity of neutral egg buoyancy of Baltic cod on the other hand, increased when Baltic cod were transferred to marine conditions (from on average $14.5 \pm 1.2$ to on average $18.7 \pm 0.9 \mathrm{psu} ; \mathrm{p}<0.001$, $t=9.49, \mathrm{df}=56$ ), although still significantly lower than for Gullmaren cod (on average 21.4 $\pm 1.3 ; \mathrm{p}<0.001, t=4.41$, $\mathrm{df}=16$ ). Egg size, known to affect egg buoyancy (Kjesbu et al. 1992, Nissling et al. 1994, Thorsen et al. 1996),

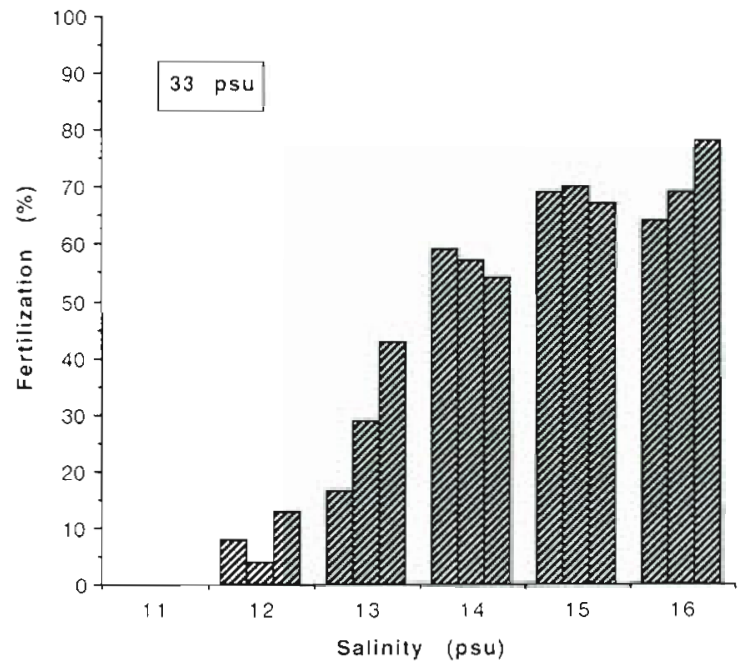

Fig. 5. Gadus morhua. Percentage of fertilized eggs after fertilization at different salinities using 3 Baltic cod males raised in marine conditions ( 30 to $34 \mathrm{psu}$ ) from the egg stage to maturity

differed significantly between the 2 populations (on average $1.66 \pm 0.07$ for Baltic cod and $1.44 \pm 0.06 \mathrm{~mm}$ for cod from the Gullmaren fjord; $\mathrm{p}<0.001, t=12.05$, $\mathrm{df}=43$ ). After transfer of Gullmaren cod to brackish conditions, egg size increased slightly, although not significantly $(\mathrm{p}=0.229, t=1.23, \mathrm{df}=24)$, whereas there was a significant decrease in egg size for Baltic cod when fish were transferred to marine conditions $(\mathrm{p}<0.001, t=4.44$,

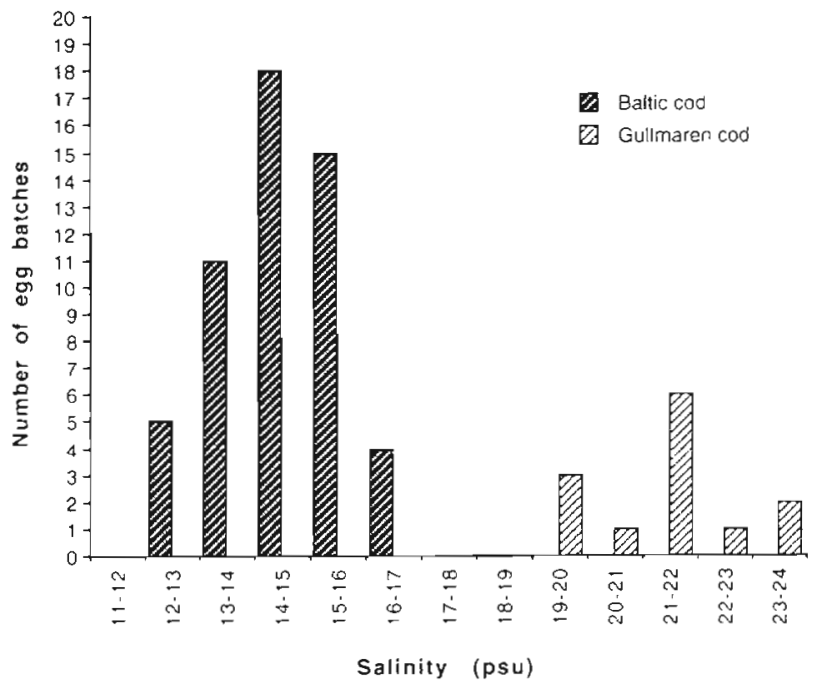

Fig. 6. Gadus morhua. Salinity of neutral egg buoyancy of 53 batches from different Baltic cod females kept at 7 psu (trom Nissling et al. 1994) and 13 batches of different Gullmaren cod fernales kept at 30 to 34 psu, determined by measurement of egg specific gravity 
Table 1. Gadus morhua. Salinity of neutral egg buoyancy and of spermatozoa activation together with measurements of egg size and salinity of ovarian fluid and seminal plasma for Baltic and Gullmaren cod, kept at 7 and at 30 to 34 psu, respectively. Mean values \pm standard deviation

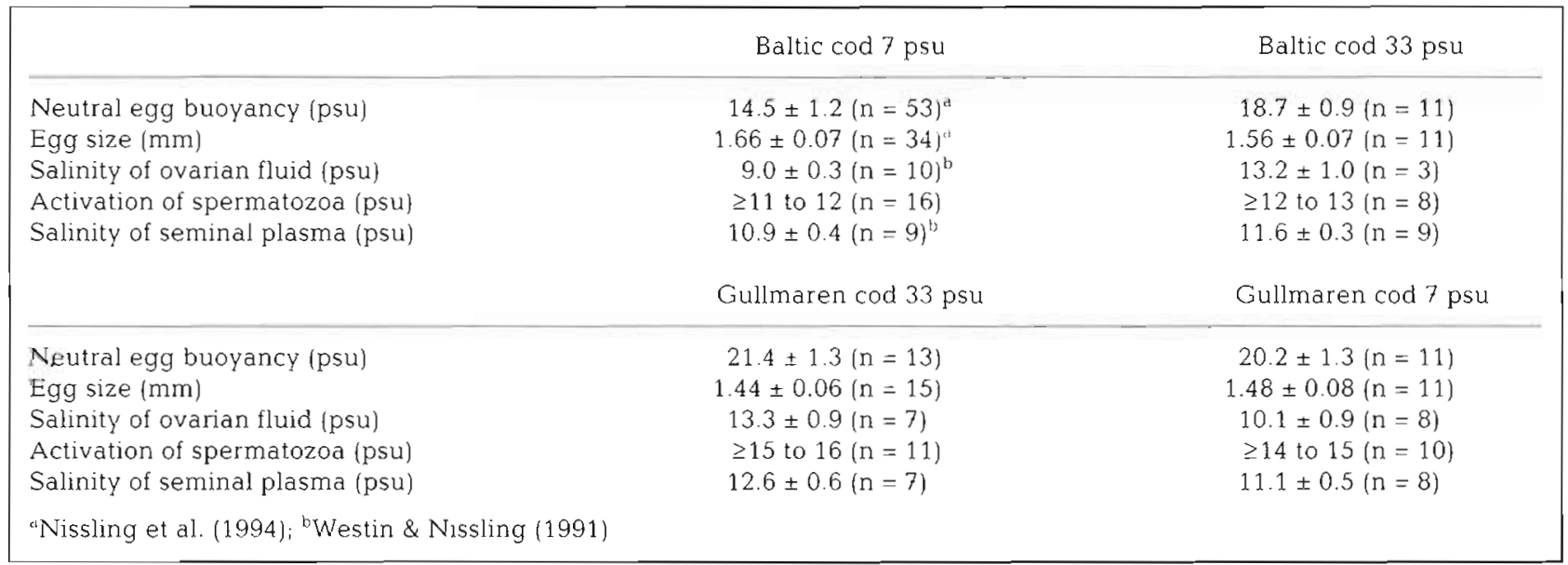

$\mathrm{df}=43)$. However, differences between the 2 stocks remained, i.e. on average $1.66 \mathrm{~mm}$ compared to $1.48 \mathrm{~mm}$ $(\mathrm{p}<0.001, t=7.71, \mathrm{df}=43)$ at brackish conditions and $1.56 \mathrm{~mm}$ compared to $1.44 \mathrm{~mm}$ in marine conditions ( $\mathrm{p}<$ $0.001, t=4.22, \mathrm{df}=24$ ) respectively. Thus, salinity of neutral buoyancy differed between Baltic cod and cod from the Gullmaren fjord and was only somewhat affected by transfer from a marine to a brackish environment.

\section{Osmolality of seminal plasma and ovarian fluid}

Salinity of seminal plasma differed significantly between Baltic cod and cod from the Gullmaren fjord when fish were kept in their respective natural environments, $10.9 \pm 0.4$ and $12.6 \pm 0.6$ psu respectively (Table $1 ; p<$ $0.001, t=7.25, \mathrm{df}=14$ ). After transfer, osmolality decreased significantly $(\mathrm{p}<0.001, t=5.20, \mathrm{df}=13)$ when Gullmaren cod was kept at brackish conditions and increased $(\mathrm{p}<0.001, t=5.02, \mathrm{df}=16)$ when Baltic cod was kept in marine conditions. When kept at the same salinity there was no significant difference in salinity of seminal plasma between the stocks at 7 psu ( $p=0.230, t=$ $1.15, \mathrm{df}=15$ ), but at 30 to 34 psu measurements revealed a significant difference $(p \approx 0.001, t=4.17, \mathrm{df}=14$ ). A similar pattern is evident concerning salinity of ovarian fluid (Table 1). Osmolality differed significantly ( $\mathrm{p}<$ $0.001, t=13.3, \mathrm{df}=14$ ) between Baltic cod kept at 7 psu and cod from Gullmaren kept at 30 to 34 psu and increased for transferred Baltic cod ( $p<0.001, t=12.41$, df $=10)$ and decreased for transferred Gullmaren cod $(p<$ $0.001, t=6.76, \mathrm{df}=13 \mathrm{j}$. No difference in ovarian osmolality of the 2 stocks existed when both were maintained at 30 to 34 psu $(p=0.802, t=0.26$, $d f=8)$ but a small difference remained when kept at 7 psu $(0.05>p>0.01, t=$
$3.68, \mathrm{df}=15)$. Thus, the present investigation shows that osmolality of both seminal plasma and ovarian fluid change according to ambient salinity.

\section{Spermatozoa mobility and egg buoyancy of cod in different areas}

In Fig. 7 salinity of spermatozoa activation is shown for cod caught in different areas and, correspondingly, Fig. 8 shows salinity of neutral egg buoyancy. Cod caught off Gotland (SD 28) and in the Bornholm Basin (SD 25) displayed equal salinity requirements for spermatozoa activation ( $\geq 11$ to 12 psu) and the same egg specific gravity (neutral egg buoyancy achieved at $14.5 \pm 1.2$ and at $14.3 \pm 1.6$ psu respectively). Similarly, cod caught in The Sound (SD 23) displayed the same salinity requirements as cod caught in the Gullmaren fjord: activation of the spermatozoa at $\geq 15$ to 16 psu and neutral egg buoyancy at $21.2 \pm 1.2$ and $20.8 \pm$ 0.7 psu respectively when kept in marine conditions and at $\geq 14$ to 15 psu and at $20.2 \pm 1.3$ and $19.9 \pm 3.6$ psu respectively after transference to $7 \mathrm{psu}$. No individuals showing characteristics of Gullmaren cod were found east of the island Bornholm (SDs 25 and 28) and no individuals with characteristics of Baltic cod were found in the Gullmaren fjord or in The Sound (SD 23). Individuals caught in the Arkona basin (SD 24), on the other hand, displayed characteristics of either cod caught east of the island Bornholm or cod caught in The Sound or in the Gullmaren fjord. Salinity of spermatozoa activation occurred at $\geq 14$ to 15 psu for 21 males and at $\geq 11$ to 12 psu for 4 males. Measurements of egg specific gravity (4 females), revealed neutral egg buoyancy at $13.7 \pm 1.3 \mathrm{psu}$, i.e. resembling cod caught east of the island Bornholm. 


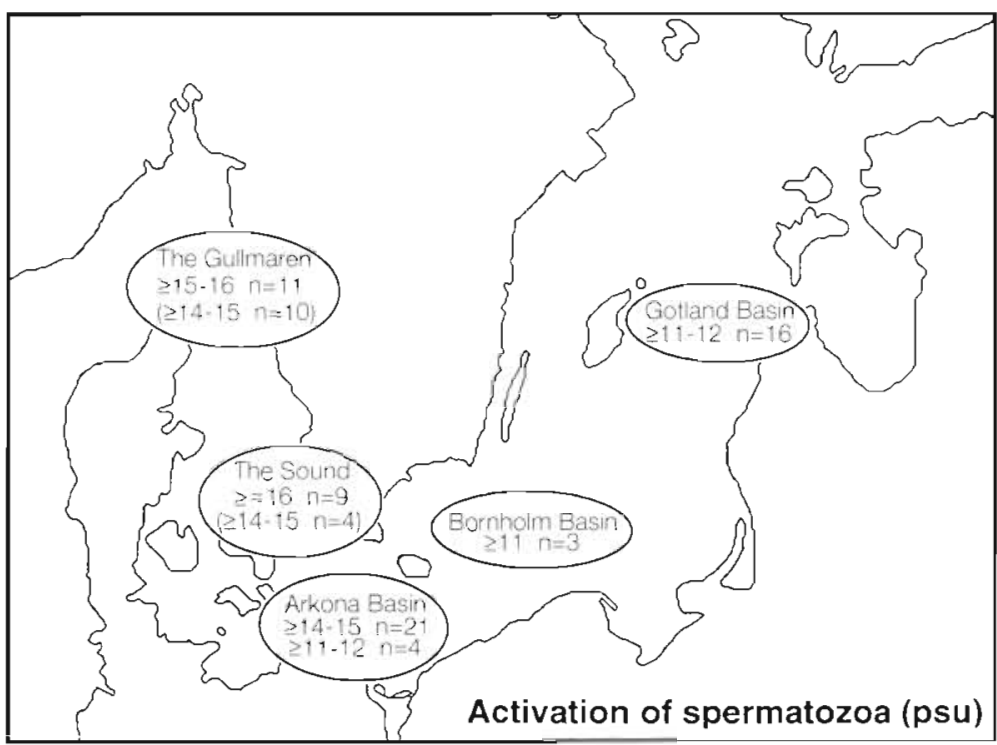

Fig. 7 Gadus morhua. Salinity of spermatozoa activation for cod caught in different areas (figures within parentheses represent measurements on fish transferred to brackısh water conditions)

\section{DISCUSSION}

With the exception of genetic characteristics most marks or characteristics that have been used in attempts to discriminate between fish stacks can be highly influenced by environmental conditions (Pella \& Milner 1987). The present study differs from most methods used by studying the functioning of fish in the environment, i.e. salinity requirements for successful spawning. The idea was originally brought up by Solemdal who compared flounder Pleuronectes flesus from the Baltic with flounder from Norwegian waters (Solemdal 1967, 1970), but it has up to now not been used in the context of stock discrimination and potential stock interbreeding.

At isoosmotic conditions in the testis, spermatozoa are immobile. In marine teleosts, spermatozoa are activated at hyperosmotic conditions after discharge into the water (Morisawa \& Suzuki 1980, Stoss 1983) The present investigation shows that differences in salinity requirements for spermatozoa activation among cod stocks exist and that fertilization success at different salinities is determined by the spermatozoa activity. Baltic cod males were potent to fertilize eggs at 11 to 12 psu and higher as opposed to males from the Gullmaren cod requiring $\geq 15$ to $16 \mathrm{psu}$ occurred at salinities with immobile spermatozoa. Actively swimming or vibrating spermatozoa were necessary. This implies that fertilization success depends on salinity, i.e. in the brackish water of the Baltic Sea fertilization success varies in accordance with hydrographic conditions.

The mechanism of achieving buoyancy includes reduction of density by the accumulation of less dense components. For cod eggs, low specific gravity is mainly obtained by a high water content acquired during the final maturation in the ovary (Craik \& Harvey 1984, 1987). Adaptation of pelagic eggs to maintain neutral buoyancy in less saline water includes an increase in size (Strodtmann 1918, Mielck \& Künne 1935, Kändler 1944, Kjesbu et al 1992) and water content (Thorsen et al. 1996). Egg specific gravity varies with egg size and is related to both female size and batch number during the spawning season (cod being a multiple batch spawner) [Kjesbu et al. 1992 (Norwegian coastal cod); Vallin \& Nissling unpubl. (Baltic cod)], i.e. vary somewhat within a stock. However, differences in egg specific gravity among cod stocks exist. Arcto-Norwegian cod display neutral egg buoyancy at 29.5 to 33 psu (Solemdal \& Sundby 1981, Kjesbu et al. 1992), Belt Sea cod and cod for successful fertilization. No fertilization

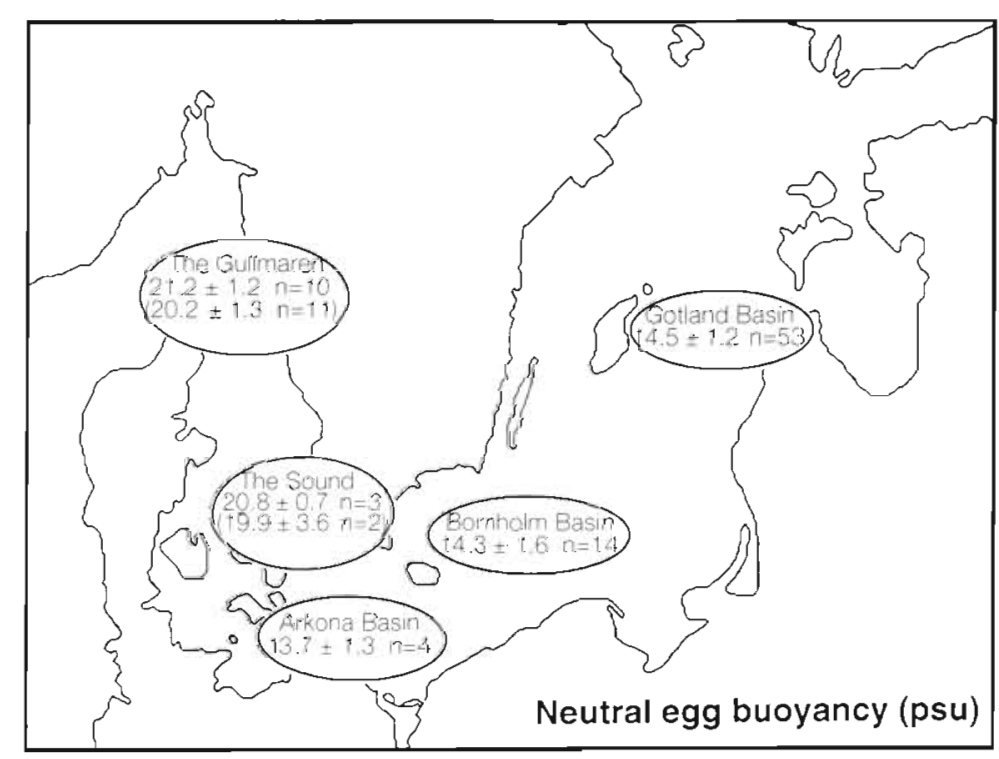

Fig. 8. Gadus morhua. Salinity of neutral egg buoyancy for cod caught in different areas (figures within parentheses represent measurements on fish transferred to brackish water conditions). Data from the Bornholm Basin obtaıned from P. Solemdal, Institute of Marine Research, Bergen, Norway (pers. comm.) 
from the Gullmaren fjord obtain neutral egg buoyancy at 19.6 to 23.6 psu (present study) and Baltic cod at $14.5 \pm 1.2$ psu (Nissling et al. 1994). Opportunities for achieving neutral egg buoyancy depend on water density, primarily salinity, implicating that opportunities for successful egg development vary according to hydrographic conditions.

Osmotic conditions in the testis suppress spermatozoa mobility and osmotic conditions in the ovary determine egg specific gravity (Stoss 1983, Craik \& Harvey 1984, Thorsen et al. 1993). This indicates that changes in osmolality of seminal plasma and ovarian fluid in accordance with ambient salinity (Kändler \& Tan 1965 , Solemdal 1967, present study) might cause a change in salinity of spermatozoa activation and salinity of neutral egg buoyancy as a result of phenotypic plasticity. The present study shows that, despite changed osmolality in fish transferred from a low to a high salinity or vice versa, only minor changes occurred in salinity of spermatozoa activation and salinity of neutral egg buoyancy. Similar to the results obtained in the present study, transfer of flounder from brackish to marine conditions showed only minor changes in egg specific gravity (Solemdal 1971, 1973). The change in egg specific gravity was the same after 4 to 5 mo as it was after $3 \mathrm{wk}$ and did not change over the course of $2 \mathrm{yr}$, i.e. the adaptation occurred immediately in accordance with changes in ovarian osmolality (Solemdal 1971). Further, salinity of spermatozoa activation changed from $\geq 15-16$ psu to $\geq 14-15$ psu when fish from marine areas were transferred to brackish conditions. This is consistent with salinity of spermatozoa activation for 21 individuals in brackish conditions in the Arkona Basin (SD 24) (Fig. 7) suggesting that this minor change in salinity of spermatozoa activation can be referred to as the phenotypic plasticity of the western stock. The ultimate evidence for evaluating phenotypic plasticity potentially resulting in different tolerance as adults is to study individuals that have been raised in different conditions. The fact that Baltic cod males, raised in fully marine conditions from the embryo stage, were able to fertilize eggs at 12 psu (present study) strongly suggests that salinity of spermatozod activation is a fixed stock specific characteristic. The difference in salinity of spermatozoa activation between Baltic and Belt Sea cod (present study) can thus not be referred to as phenotypic plasticity. Further evidence of differences in salinity requirements for successful spawning between populations exists. Flounder occur in the Baltic as 2 stocks, one spawning in the deep basins with pelagic eggs and the other in shallow areas with demersal eggs (Strodtmann 1918, Mielck \& Künne 1935). Despite inhabiting the same area, i.e. at 6 to 8 psu, both salinity of spermatozoa activation and salinity of neutral egg buoyancy differ between the stocks [activation of spermatozoa at 10 to 11 psu and -5.5 psu, and neutral egg buoyancy at 14 to 16 psu and 20 to 21 psu respectively (Solemdal 1967, 1970, Nissling \& Westin unpubl.)]. The above results suggest that adaptation to ambient salinity is limited and that these characteristics are specific for the respective populations; characteristics that probably have evolved under longterm selection with salinity as an evolutionary force. Baltic cod must be regarded as unique in that they are adapted to the brackish environment and thus cannot be replaced by immigration of fish from the western stock in a short-term perspective.

Being specific for respective stock these characteristics might be used for discrimination of stocks on an individual basis. Using this, occurrence of individuals from different stocks in different areas can be evaluated as suggested in Figs. 7 \& 8. Although the number of individuals studied is low, the present study suggests that individuals of both stocks occur in the Arkona Basin (SD 24), whereas no individuals resembling Baltic cod were found in The Sound (SD 23) or in the Gullmaren fjord. Accordingly, no individuals resembling Belt Sea cod were found east of the Bornholm island (SDs 25 and 28). The border between the stocks is generally regarded as the longitude $14^{\circ} 30^{\prime} \mathrm{E}$ (Bagge et al. 1994) (Fig. 1). However, in cod stock discriminations in the Baltic, the area west of Bornholm is sometimes considered a transition area between Belt Sea and Baltic cod with intermediate mean values concerning alloenzyme analysis and morphometric characteristics for samples in this area (see Bagge \& Steffensen 1989, Bagge et al. 1994). The present study indicates that cod of both the eastern and the western stock occur in the Arkona Basin (SD 24). Intermediate mean figures concerning the above mentioned characteristics can thus be expected in samples from this area since individuals from both stocks seem to be present.

The results suggest that interaction between the stocks is possible, since individuals of both kinds occur in the Arkona Basin (SD 24) and salinity requirements for both Baltic and Belt Sea cod are fulfilled (salinity in the bottom water ranging from 15 to 22 psu). However, there is a discrepancy in the time of spawning, although some overlap exists. Spawning of Belt Sea cod occurs in January-April (peak in FebruaryMarch), whereas spawning of Baltic cod takes place between March and September, with peak spawning occurring from May to August (Bagge et al. 1994, Klenz 1994). Further, an observation of spawning cod occurring in the Arkona Basin in mid August 1995 (authors' obs.) indicates, with respect to time of spawning, that spawning of eastern Baltic cod may occur in this area. Due to differences in spawning time, time of sampling is probably of great importance in evaluating distribution of spawning areas. 
Concerning possibilities for successful spawning in the deep Baltic basins, the results suggest that the low salinity water ( 10 to $13 \mathrm{psu}$ ) in the Gdansk and Gotland Basins prevents individuals from the western stock from spawning successfully. In the Bornholm Basin (SD 25), on the other hand, with salinities in the bottom water generally ranging from 13 to 18 psu, interactions may occur, since Belt Sea cod males require 14 to 15 psu salinity for activation of the spermatozoa. However, Belt Sea cod females (salinity of neutral buoyancy at $\sim 19$ to $21 \mathrm{psu}$ ) probably do not spawn successfully in the Bornholm Basin. Immediately following a saline water inflow, however, high salinities occasionally occur in the Bornholm Basin, e.g. 20 to 21 psu following an inflow in 1951 (Fonselius 1962) and 20 psu after the inflow in 1993 (Matthäus et al. 1994, Matthäus \& Lass 1995), suggesting that also Belt Sea cod females occasionally may spawn successfully in this area.

Environmental conditions in the deep basins vary greatly depending on the frequency of inflows. Long periods of stagnation occur (periods lasting for several years, e.g. 16 yr between the major inflows in 1976-77 and in 1993) with decreasing salinity and oxygen deficiency in the bottom water (Fonselius 1962, 1988, Frank et al. 1987, Matthäus 1993). During the last stagnation period salinities of $<15$ psu and oxygen concentrations of $<1 \mathrm{ml} \mathrm{l}^{-1}$ in the bottom water occurred from the mid 1980s to the early 1990s (Franck \& Matthäus 1992). Such periods may prevent spawning of Belt Sea cod in the deep basins and act as an ecological barrier, inhibiting interactions and separating the stocks.

Acknowledgements. The authors thank the crew of RV 'Argos' and Lars Vallin and Roger Larsson for assistance during the experiments, Karin Frohlund for preparing the maps and 3 anonymous referees for valuable comments. The investigation was supported by the Gunvor and Josef Aners Foundation, the Carl Trygger Foundation and the Swedish Natural Science Research Council and was partly conducted within the project AIR2-CT94-1226.

\section{LITERATURE CITED}

Aro E (1989) A review of fish migration patterns in the Balth Rapp PV Réun Cons Int Explor Mer 190:72-96

Bagge O. Steffensen E (1989) Stock identification of demersal fish in the Baltic. Rapp PV Réun Cons Int Explor Mer 190: $3-16$

Bagge O, Thurow F (1993) The Baltic cod stock, fluctuations and possible causes. ICES Mar Sci Symp 198:254-268

Bagge O, Thurow F, Steffensen E, Bay J (1994) The Baltic cod. Dana 10:1-28

Brander K (1994) Spawning and life history information for North Atlantic cod stocks. ICES Coop Res Rep 205

Chakraborty R, Leimar O (1987) Genetic variation within a subdivided population. In: Ryman N, Utter F (eds) Population genetics \& fishery management. University of Washington Press, Seattle, p 89-119
Coombs SH (1981) A density-gradient column for determming the specific gravity of fish eggs, with particular reference to eggs from the mackerel Scomber scombrus. Mar Biol 63:101-106

Craik JCA, Harvey SM (1984) Biochemical changes occurring during final maturation of eggs of some marme and freshwater teleosts. J Fish Biol 24:599-610

Craik JCA, Harvey SM (1987) The causes of buoyancy in eggs of marine teleosts. J Mar Biol Assoc UK 67:169-182

Dahle G (1991) Cod, Gadus morhua L., populations identified by mitochondrial DNA. J Fish Biol 38:295-303

Dahle G, Jorstad KE (1993) Haemoglobin variation in cod - a reliable marker for Arctic cod (Gadus morhua L.). Fish Res 16:301-311

Elmgren R, Aneer G, Hansson S (1989) Food web analysis of the Baltic ecosystem. In: Wullf $F$ (ed) Large-scale environmental effects and ecological processes in the Baltic Sea, Research Programme. Swedish Environmental Protection Agency, Rep No. 3849, p 167-185

Fonselius SH (1962) Hydrography of the Baltic deep basins. Fishery Board of Sweden, Göteborg Series Hydrography 13

Fonselius SH (1988) Long-term trends of dissolved oxygen, pH and alkalinity in the Baltic deep basins. ICES Int Counc Explor Sea Comm Meet C:23

Franck H, Matthäus W (1992) The absence of effective major inflows and the present changes in the hydrographic conditions of the central Baltic deep water. In: Bjornestad $E_{\text {, }}$ Hagerman L, Jensen K (eds) Proc 12th Baltic Manne Biologists Symp. Olsen \& Olsen, Fredensborg, p 53-60

Franck H, Matthäus W, Sammler R (1987) Major Baltic inflows this century. Beitr Meereskd 56:81-82

Fyhn UEH, Brix O, Nævdal G, Johansen T (1994) New variants of haemoglobins of Atlantic cod: a tool to discruminate between coasta] and arctic cod populations. ICES Mar Sci Symp 198:666-670

Grauman GB (1973) Investigations of factors influencing fluctuations in the abundance of Baltic cod. Rapp PV Réun Cons Int Explor Mer 164:73-76

Grauman GB (1974) Investigations on the spawning of Baltic cod in 1968-1970. Rapp PV Réun Cons Int Explor Mer 166: $7-9$

Hansson S, Rudstam LG (1990) Eutrophication and Baltic fish communities. Ambio 19:123-125

Howell BR, Child AR, Houghton RG (1991) Fertilization rate in a natural population of the common sole. ICES J Mar Sci 48:53-59

Kändler R (1944) Untersuchungen über den Ostseedorsch während der Forschungsfahrten m.t dem RFD 'Poseidon' in den Jahren 1925-1938. Ber Dtsch Wiss Komm Meeresforsch 11(2): 137-245

Kändler R, Tan EO (1965) Investigations on the osmoregulation in pelagic eggs of gadoid and flatfishes in the Baltic. Part 1: Changes in volume and spec. gravity at different salinities. ICES Int Counc Explor Sea Comm Meet No 43

Kjesbu OS, Kryvi H, Sundby S, Solemdal P (1992) Buoyancy variations in eggs of Atlantic cod (Gadus morhua L.) in relation to chorion thuckness and egg size: theory and observations. J Fish Biol 41:581-599

Klenz B (1994) Distribution of ichthyoplankton in the Western Baltic regarding cod recruitment. ICES Int Counc Explor Sea Comm Meet Q:5

Matthäus W (1993) Major inflows of highly saline water into the Baltic Sea - a review. ICES Int Counc Explor Sea Comm Meet C:52

Matthaus W, Lass HU (1995) The recent salt inflow into the Baltic Sea. J Phys Oceanogr 25:280-286 
Matthäus W, Nehring D, Nausch G (1994) Effects of the inflows of salt-rich water during 1993 and early 1994 in the central Baltic Sea. Int Counc Explor Sea Comm Meet Q:3

Mielck W, Künne C (1935) Fischbrut und Planktonuntersuchungen auf dem RFD Poseidon in der Ostsee 1931. Helgol Wiss Meeresunters 19:1-120

Morisawa M. Suzuki K (1980) Osmolality and potassium ion: their role in initiation of sperm motility in teleosts. Sclence 210:1145-1146

Mork J, Ryman N, Ståhl G, Utter F, Sundnes G (1985) Genetic variations in cod (Gadus morhua): little divergence throughout its range. Can J Fish Aquat Sci 42:1580-1587

Nissling A, Kryvi $H$, Vallin L (1994) Variation in egg buoyancy of Baltic cod Gadus morhua and its implications for egg survival in prevailing conditions in the Baltic Sea. Mar Ecol Prog Ser 110:67-74

Nissling A, Westin L (1991) Egg buoyancy of Baltic cod (Gadus morhua) and its implications for cod stock fluctuations in the Baltic. Mar Biol 111:33-35

Pella JJ, Milner GB (1987) Use of genetic marks in stock composition analysis. In: Ryman N, Utter F (eds) Population genetics \& fishery management. University of Washington Press, Seattle, p 247-276

Solemdal P (1967) The effect of salinity on buoyancy, size and development of flounder eggs. Sarsia 29:431-442

Solemdal P (1970) The reproductive adaptation of marine teleosts to water of low salinity. ICES Int Counc Explor Sea Comm Meet F:30

This article was submitted to the editor
Solemdal P (1971) Prespawning flounders transferred to different salinities and the effects on their eggs. Vie Milieu Suppl 22:409-423

Solemdal P (1973) Transfer of Baltic flatfish to a marine environment and the long term effects on reproduction. Oikos Suppl 15:268-276

Solemdal P, Sundby S (1981) Vertical distribution of pelagic fish eggs in relation to species, spawning behaviour and wind conditions. ICES Int Counc Explor Sea Comm Meet G:77

Stoss J (1983) Fish gamete preservation and spermatozoan physiology. In: Hoar WS, Randall DJ, Donaldson EM (eds) Fish physiology, Vol IXB. Academic Press, New York, p 305-350

Strodtmann S (1918) Weitere Untersuchungen über Ostseefische, III. Helgol Wiss Meeresunters 14:31-95

Thorsen A, Fyhn HJ, Wallace RA (1993) Free amino acids as osmotic effectors for oocyte hydration in marine fishes. In: Walther BT, Fyhn HJ (eds) Physiological and biochemical aspects of fish development. Univ of Bergen, p 94-98

Thorsen A, Kjesbu OS, Fyhn HJ, Solemdal P (1996) Physiological mechanisms of egg buoyancy in brackish water cod (Gadus morhua L.). J Fish Biol 48:457-477

Westerberg $\mathrm{H}$ (1994) The transport of cod eggs through Oresund. ICES Int Counc Explor Sea Comm Meet Q:4

Westin L, Nissling A (1991) Effects of salinity on spermatozoa motility, percentage of fertilized eggs and egg development of Baltic cod (Gadus morhua L.), and implications for cod stock fluctuations in the Baltic. Mar Biol 108:5-9

Manuscript first received: September 9, 1996

Revised version accepted: March 24, 1997 